\title{
Intermetallic Formation and Fluidity in Sn-Rich Sn-Cu-Ni Alloys
}

\author{
C.M. GOURLAY, ${ }^{1,3}$ K. NOGITA, ${ }^{2}$ J. READ, ${ }^{2}$ and A.K. DAHLE ${ }^{2}$ \\ 1.-Department of Materials, Imperial College, London SW7 2AZ, UK. 2.-Materials Engineering, \\ The University of Queensland, Brisbane, QLD 4072, Australia. 3.—e-mail: c.gourlay@imperial. \\ ac.uk
}

This paper investigates the phase equilibria and solidification behavior of $\mathrm{Sn}-\mathrm{Cu}-\mathrm{Ni}$ alloys with compositions in the range of $0 \mathrm{wt} . \%$ to $1.5 \mathrm{wt} . \% \mathrm{Cu}$ and 0 wt.\% to 0.3 wt.\% Ni. The isothermal section at $268^{\circ} \mathrm{C}$ in the Sn-rich corner was determined. No evidence for a ternary phase was found, and the section is in good agreement with past experimental studies that report wide solubility ranges for $(\mathrm{Cu}, \mathrm{Ni})_{6} \mathrm{Sn}_{5}$ and $(\mathrm{Ni}, \mathrm{Cu})_{3} \mathrm{Sn}_{4}$. The vacuum fluidity test was applied to compositions that are liquid at $268^{\circ} \mathrm{C}$ to map the variation in microstructure and flow behavior with composition in this system. Significant variations in fluidity length were measured among the $\mathrm{Sn}-\mathrm{Cu}-\mathrm{Ni}$ alloys, and the variations correlate with the microstructure that develops during solidification. The generated fluidity map enables the selection of $\mathrm{Sn}-\mathrm{Cu}-\mathrm{Ni}$ solder compositions that exhibit good fluidity behavior during solidification and form near-eutectic microstructures.

Key words: $\mathrm{Pb}$-free, soldering, IMC, phase equilibria, isothermal section, $\mathrm{Cu}-\mathrm{Ni}-\mathrm{Sn}$, solidification

\section{INTRODUCTION}

The Sn-Cu-Ni system is of fundamental importance to many solder reactions. For example, thorough knowledge of the $\mathrm{Sn}-\mathrm{Cu}-\mathrm{Ni}$ system is required to understand the soldering of $\mathrm{Sn}-\mathrm{Ag}-\mathrm{Cu}$ alloys onto $\mathrm{Ni}$ substrates or soldering with quaternary $\mathrm{Sn}-\mathrm{Ag}-\mathrm{Cu}-$ $\mathrm{Ni}$ alloys. Due to this relevance to soldering, a range of solder joint studies have been conducted using the $\mathrm{Sn}-\mathrm{Cu}-\mathrm{Ni}$ system where the $\mathrm{Cu}$ and $\mathrm{Ni}$ are initially present either in the solder alloy or in the substrate. ${ }^{1-8}$ It is now clear that, when soldering in this system, the intermetallic(s) in the reaction layer of the joint exhibit significant mutual solubility of $\mathrm{Cu}$ and $\mathrm{Ni}$, which influences both the growth kinetics of the reaction zone and the type of intermetallic compounds (IMCs) that form. ${ }^{9}$ Recently, $\mathrm{Ni}$ has also been shown to stabilize the hightemperature hexagonal allotrope of $(\mathrm{Cu}, \mathrm{Ni})_{6} \mathrm{Sn}_{5}$ at room temperature. ${ }^{10}$

In addition to research on higher-order solder reactions in which $\mathrm{Sn}-\mathrm{Cu}-\mathrm{Ni}$ is a constituent

(Received May 27, 2009; accepted September 14, 2009; published online November 13, 2009) system, there is also a growing body of research using ternary $\mathrm{Sn}-\mathrm{Cu}-\mathrm{Ni}$ alloys as solders in their own right. 1,7,8,11,12 One such solder that is in commercial production is the composition $\mathrm{Sn}-0.7 \mathrm{Cu}-0.05 \mathrm{Ni}^{13}$ Whereas $\mathrm{Sn}-0.7 \mathrm{Cu}$ solder contains $\beta$-Sn dendrites at most cooling rates, ${ }^{14} \mathrm{Sn}-0.7 \mathrm{Cu}-0.05 \mathrm{Ni}$ has been shown to have a near-eutectic microstructure. ${ }^{14} \mathrm{It}$ has also been demonstrated that small $\mathrm{Ni}$ additions significantly alter the development of the microstructure during solidification. ${ }^{15}$ Little research has been published on the phase equilibria, solidification, and microstructure formation of the very Sn-rich compositions relevant to $\mathrm{Sn}-\mathrm{Cu}-\mathrm{Ni}$ solders. ${ }^{14,16}$ Now that $\mathrm{Sn}-\mathrm{Cu}-\mathrm{Ni}$ solders are in commercial use, there is a need to improve our understanding of the metallurgy of the Sn-Cu-Ni compositions that are liquid at soldering temperatures.

There are significant discrepancies in the recent literature on the phase equilibria of $\mathrm{Sn}$-rich $\mathrm{Sn}-\mathrm{Cu}$ $\mathrm{Ni}$ alloys. For example, the liquidus projections of the Sn-rich corner by Lin et al., ${ }^{17}$ Snugovsky et al., ${ }^{16}$ and Vuorinen et al. ${ }^{2}$ are fundamentally different, as shown in Fig. 1 and in Ref. 17. A further area of uncertainty is the presence of a ternary $(\mathrm{Cu}, \mathrm{Ni})_{6} \mathrm{Sn}_{5}$-type compound: Two experimental 

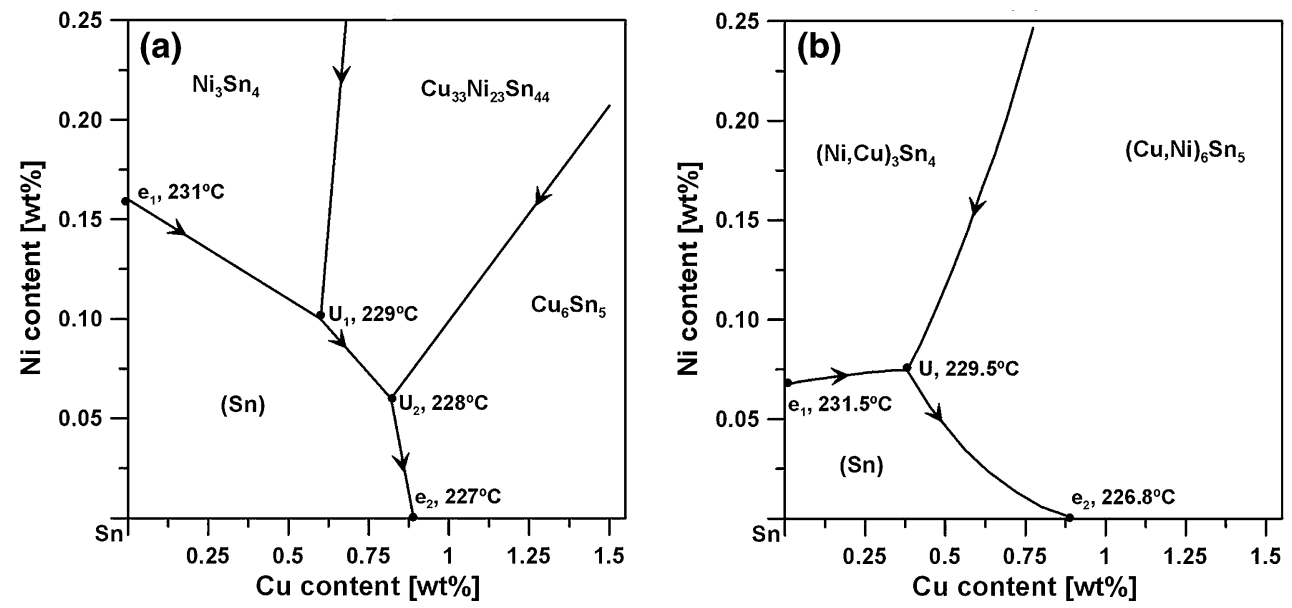

Fig. 1. Liquidus projections of the very Sn-rich corner of the Sn-Cu-Ni system from the literature. (a) Replotted data of Snugovsky et al. ${ }^{16}$ (experimentally determined). (b) Replotted data of Vuorinen et al. ${ }^{2}$ (calculated).

studies have identified the presence of $\mathrm{Cu}_{29} \mathrm{Ni}_{26}$ $\mathrm{Sn}_{45}{ }^{18}$ or $\mathrm{Cu}_{33} \mathrm{Ni}_{23} \mathrm{Sn}_{44}{ }^{16}$ in equilibrium with low-Ni-containing $(\mathrm{Cu}, \mathrm{Ni})_{6} \mathrm{Sn}_{5}$. A first-principles calculation study by $\mathrm{Yu}$ et al. predicts that $\mathrm{Cu}_{4} \mathrm{Ni}_{2} \mathrm{Sn}_{5}\left(\mathrm{Cu}_{37} \mathrm{Ni}_{18} \mathrm{Sn}_{45}\right)$ could be a ternary compound by showing that stoichiometric $(\mathrm{Cu}, \mathrm{Ni})_{6} \mathrm{Sn}_{5}$ such as $\mathrm{Cu}_{4} \mathrm{Ni}_{2} \mathrm{Sn}_{5}$ and $\mathrm{Cu}_{5} \mathrm{Ni}_{1} \mathrm{Sn}_{5}$ are more stable than other Ni contents. However, most phase equilibria studies have not found a ternary $(\mathrm{Cu}, \mathrm{Ni})_{6} \mathrm{Sn}_{5^{-}}$ type compound and instead report that $(\mathrm{Cu}, \mathrm{Ni})_{6} \mathrm{Sn}_{5}$ can contain a Ni content throughout the range from 0 at.\% to approximately 25 at.\%. ${ }^{17,19,20}$ Based on these results, Laurila et al. ${ }^{9}$ suggest that, at equilibrium at $235^{\circ} \mathrm{C}$, alloys contain mixtures of a $(\mathrm{Cu}, \mathrm{Ni})_{6} \mathrm{Sn}_{5}$ ternary compound (often denoted $\tau$ ) and low-Ni-containing $(\mathrm{Cu}, \mathrm{Ni})_{6} \mathrm{Sn}_{5}$, but that the transformation to the $\tau$-phase is extremely sluggish. They suggest that phase equilibria studies that measure $\mathrm{Ni}$ contents in $(\mathrm{Cu}, \mathrm{Ni})_{6} \mathrm{Sn}_{5}$ throughout the range of 0 at.\% to approximately 25 at.\% $\mathrm{Ni}$ are determining the metastable phase equilibria, and that soldering calculations should be based on these metastable measurements. Due to these discrepancies and uncertainties there are no reliable data for the liquidus temperatures or solidification sequences for $\mathrm{Sn}$-rich $\mathrm{Sn}-\mathrm{Cu}-\mathrm{Ni}$ alloys.

Recently, the fluidity length test, which was developed for structural casting alloys, ${ }^{21,22}$ has been applied to solder alloys. ${ }^{14,23,24}$ The maximum fluidity length, $L_{\mathrm{f}}$, is defined as the distance an initially liquid alloy can flow as it solidifies in a constant cross-section before the developing microstructure arrests flow. ${ }^{22,25}$ The test was initially applied to solders because the ability of an alloy to flow as it solidifies is important in the formation of wavesolder defects such as solder projections (icicles) and interconnection bridging. It was found that large variations in $L_{\mathrm{f}}$ exist among $\mathrm{Sn}-\mathrm{Cu}$ and $\mathrm{Sn}-\mathrm{Ag}-\mathrm{Cu}$ solder alloys and that the $L_{\mathrm{f}}$ values could be correlated with the phase equilibria using similar analyses to those applied in casting studies. ${ }^{23}$
Based on decades of casting research, it is known that $L_{\mathrm{f}}$ is strongly dependent on alloy composition. Figure 2 shows a generalized summary of the findings of a range of researchers for binary eutectic alloys ${ }^{21,22,26,27}$ involving two metallic nonfaceted phases (e.g., Sn-Pb), illustrating the influence of alloy composition on the solidification mode, the mechanism of flow stoppage, and $L_{\mathrm{f}}$. For theoretically pure metals and eutectic alloys, solidification occurs by planar growth from the walls toward the centerline, and flow stops when growth causes the planar fronts to meet (Fig. 2c). Only small impurity or alloying additions are typically required to cause nonplanar growth. In dilute alloys, columnar dendrites (with a mushy zone) grow from the edges towards the centerline and the columnar dendrites pinch off at a lower solid fraction than in pure metals, resulting in a lower $L_{\mathrm{f}}$ than in pure metals or eutectic alloys (Fig. 2d). For the compositions in the phase diagram where the freezing range is widest, alloys generally solidify as equiaxed dendrites. ${ }^{22}$ Unlike planar and columnar growth from the channel walls, where the solid is essentially stationary with liquid flowing past, equiaxed crystals can be carried in suspension. Flow stoppage occurs when the equiaxed grains at the flow tip form a solid network that can resist flow, which typically occurs at $20-50 \%$ solid. $^{28}$ Equiaxed crystals therefore arrest flow significantly earlier in the solidification process than a planar front or columnar dendrites, resulting in a shorter $L_{\mathrm{f}}$ for alloys solidifying with equiaxed dendrites (Fig. 2). Between the extremes in Fig. $2 \mathrm{~d}$ and e, solidification occurs by mixed-mode mechanisms such as the columnarequiaxed mode depicted in Fig. 2f, which has an $L_{\mathrm{f}}$ between that of the fully columnar and equiaxed modes. Detailed reviews on $L_{\mathrm{f}}$ are given in Refs. 22 and 25 .

Similar behavior to Fig. 2 was measured for $\mathrm{Sn}-\mathrm{Cu}$ and $\mathrm{Sn}-\mathrm{Ag}-\mathrm{Cu}$ alloys, ${ }^{23}$ with the notable exception that a peak in fluidity was not measured 


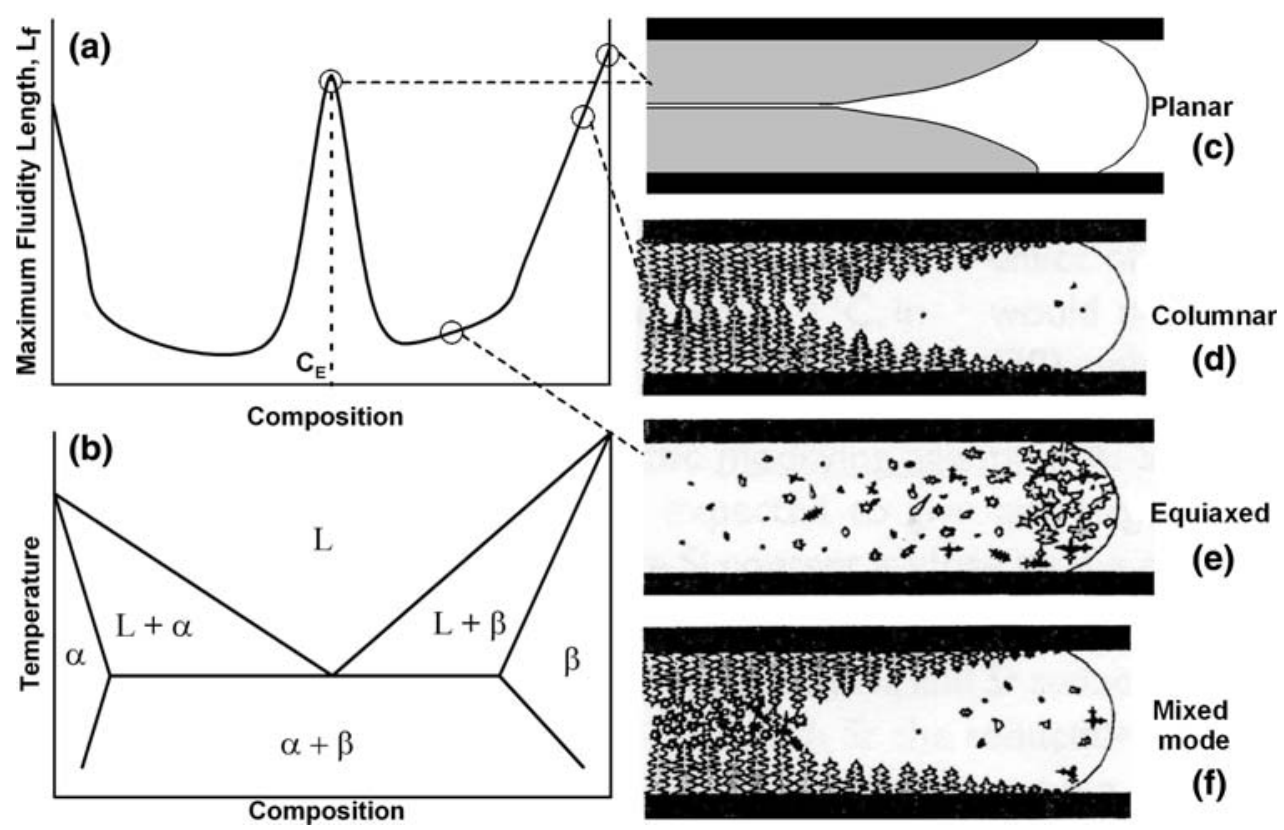

Fig. 2. Generalized summary of the influence of composition on the maximum fluidity length, $L_{\mathrm{f}}$, in simple binary eutectic systems: (a) $L_{\mathrm{f}}$ versus alloy composition at a constant initial melt superheat. (b) Binary eutectic phase diagram corresponding to the data in (a). Illustrations (c-f) depict the microstructures that arrest flow for different solidification modes.

at the eutectic composition and the $L_{\mathrm{f}}$ continued to increase at hypereutectic compositions. This difference was attributed to (i) the highly asymmetrical phase diagrams, which result in only small volume fractions of IMC forming at hypereutectic compositions in the composition ranges studied, and (ii) the fact that $\mathrm{Cu}_{6} \mathrm{Sn}_{5}$ and $\mathrm{Ag}_{3} \mathrm{Sn}$ are faceted phases, so that the eutectic coupled zone is skewed away from the Sn side and hypereutectic compositions are required to create fully eutectic microstructures at a high cooling rate. ${ }^{29}$ Further discussion on the fluidity of ternary $\mathrm{Sn}-\mathrm{Ag}-\mathrm{Cu}$ alloys (where the phase equilibria are known) is given in Ref. 23.

In the case of Sn-rich Sn-Cu-Ni alloys where the phase equilibria are currently uncertain, generating an $L_{\mathrm{f}}$ map by measuring $L_{\mathrm{f}}$ at a variety of compositions can yield important information on microstructure development during solidification as a function of solder composition. An added advantage of $L_{\mathrm{f}}$ measurements is that they are relevant to microstructure formation at the relatively high cooling rates of industrial soldering operations.

This paper is a broad study of Sn-rich $\mathrm{Sn}-\mathrm{Cu}-\mathrm{Ni}$ alloys in the range of $0 \mathrm{wt} . \%$ to $1.5 \mathrm{wt} . \% \mathrm{Cu}$ and
0 wt. $\%$ to 0.3 wt. $\% \mathrm{Ni}$. The aims are to deduce the phase equilibria, including the liquidus contour, at $268^{\circ} \mathrm{C}$ and to measure the fluidity length of compositions that are liquid at $268^{\circ} \mathrm{C}$. Fluidity length measurements and microstructural characterization are then used to map the influence of composition on both flow behavior and microstructure formation during solidification of $\mathrm{Sn}-\mathrm{Cu}-\mathrm{Ni}$ alloys.

\section{EXPERIMENTAL PROCEDURES}

Sn-rich Sn-Cu-Ni alloys with compositions in the range of 0 wt. $\%$ to $1.5 \mathrm{wt} . \% \mathrm{Cu}$ and 0 wt.\% to $0.3 \mathrm{wt} . \%$ $\mathrm{Ni}$ were made by mixing commercial-purity Sn with two master alloys of nominal composition Sn-10Cu and $\mathrm{Sn}-10 \mathrm{Ni}$ to create alloys with a purity similar to that of industrial solders. The compositions of the Sn and master alloys are shown in Table I. Alloying was conducted in a 1-L clay-bonded graphite crucible by melting the appropriate mixture of the three ingots at $400^{\circ} \mathrm{C}$ for $3 \mathrm{~h}$. The bulk composition $\left(C_{0}\right)$ of each melt was measured by taking chemical analysis samples at $400^{\circ} \mathrm{C}$ and testing them by $\mathrm{x}$-ray fluorescence (XRF) spectroscopy in a Shimadzu

Table I. Compositions of the Sn and two master alloys used to create the Sn-Cu-Ni solder alloys

\begin{tabular}{|c|c|c|c|c|c|c|c|c|c|}
\hline & $\mathrm{Cu}($ wt.\%) & $\mathrm{Ni}$ (wt.\%) & Pb (wt.\%) & Ag (wt.\%) & Bi (wt.\%) & Zn (wt.\%) & Fe (wt.\%) & Sb (wt.\%) & As (wt.\%) \\
\hline 99.9 & & 0 & & & & & & & \\
\hline $\mathrm{Sn}-10 \mathrm{Cu}$ & & 0.0129 & 49 & 02 & 99 & 02 & & 92 & 09 \\
\hline $\mathrm{Sn}-10 \mathrm{Ni}$ & 0.0022 & 10.1 & 0.0270 & $<0.0002$ & $<0.0002$ & $<0.0002$ & 0.0051 & 0.0073 & 0.0043 \\
\hline
\end{tabular}

The balance is Sn: $99.9 \%$ Sn determined by XRF spectroscopy. Master alloys determined by inductively coupled plasma-atomic emission spectroscopy (ICP-AES). 


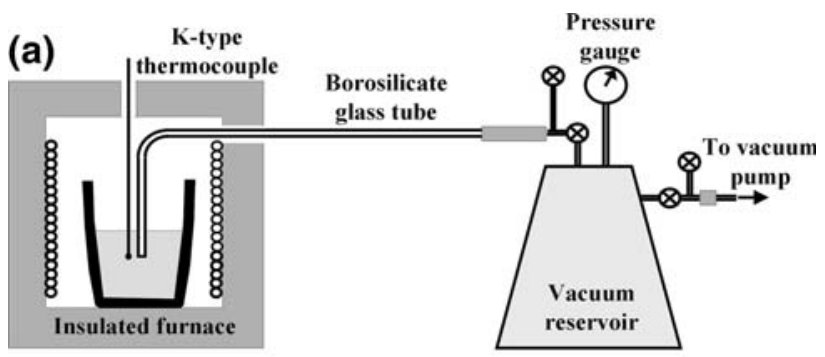

(b)

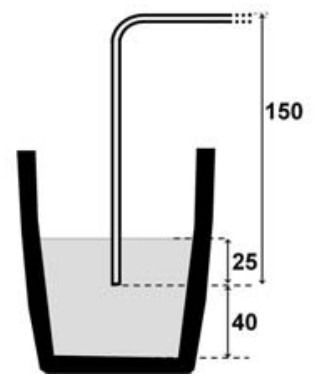

Fig. 3. (a) Schematic diagram of the fluidity apparatus. (b) Detail of crucible and glass tube, quantifying the tube position in the alloy. Dimensions are in millimeters.

XRF-1700. The remaining melt was cast into ingots to be remelted later.

The first series of experiments used the same vacuum fluidity length apparatus as in Ref. 23, which is based on that developed by Ragone et al. ${ }^{21}$ and is shown schematically in Fig. 3. It is common for fluidity length experiments to be conducted at a constant melt superheat (i.e., $T-T_{\text {liquidus }}=$ constant) for all compositions. ${ }^{22,25}$ However, this was not possible since the liquidus temperatures of the $\mathrm{Sn}-\mathrm{Cu}-\mathrm{Ni}$ alloys were not known. A constant melt temperature was therefore used instead, and $268^{\circ} \mathrm{C}$ was selected since this is at the upper end of typical bath temperatures used in wave soldering. It was expected that some compositions would be solid-liquid mixtures at $268^{\circ} \mathrm{C}$ and the same fluidity apparatus was therefore used for two types of experiment:

1. To determine the liquid composition $\left(C_{\mathrm{L}}^{268}\right)$ for bulk compositions $\left(C_{0}\right)$ that are partially solid at $268^{\circ} \mathrm{C}$.

2. To determine the maximum fluidity length, $L_{\mathrm{f}}$, as a function of composition for bulk compositions $\left(C_{0}\right)$ that are fully liquid at $268^{\circ} \mathrm{C}$.

In both cases, the following procedure was followed: $1500 \mathrm{~g}$ of alloy was remelted in a 1-L boron nitride (BN)-coated clay-bonded graphite crucible. A borosilicate glass tube was then placed in the melt, with the majority of the tube held level outside the furnace, as depicted in Fig. 3. The alloy was held in the furnace at $268^{\circ} \mathrm{C}$ for at least $1 \mathrm{~h}$ to thermally equilibrate the system. Flow was then initiated by releasing a valve between the vacuum reservoir and the flow tube. At the end of a fluidity test, the flow distance was measured, giving a value of $L_{\mathrm{f}}$. After
Table II. Reported densities of phases $\left(\mathrm{kg} \mathrm{m}^{-3}\right)$

\begin{tabular}{|c|c|c|c|}
\hline$\overline{\mathbf{S n}^{\mathbf{a}}}$ & $\mathbf{S n}^{\mathbf{b}}$ & $\mathrm{Cu}_{6} \mathrm{Sn}_{5}{ }^{\mathrm{b}}$ & $\mathrm{Ni}_{3} \mathrm{Sn}_{4}^{\mathrm{b}}$ \\
\hline $\begin{array}{l}6986 \\
\text { Ref. 31 }\end{array}$ & $\begin{array}{c}7310 \\
\text { Ref. } 31\end{array}$ & $\begin{array}{c}8270 \\
\text { Ref. } 32\end{array}$ & $\begin{array}{c}8420 \\
\text { Ref. 33 }\end{array}$ \\
\hline
\end{tabular}

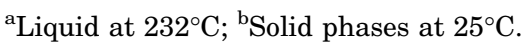

each experiment, the mass of alloy removed was measured and a similar mass was added to the melt to ensure a consistent alloy height in the crucible in subsequent experiments (Fig. 3b). Five experiments were conducted for each composition. The alloy composition was varied whilst the following experimental parameters were maintained:

- Mass of alloy in crucible $=1500 \pm 0.2 \mathrm{~g}$

- Melt temperature $=268 \pm 1^{\circ} \mathrm{C}$

- Room temperature $=23 \pm 6^{\circ} \mathrm{C}$

- Partial vacuum $=-80 \pm 2 \mathrm{kPa}$

- Outer diameter of borosilicate glass tube $=6 \pm$ $0.15 \mathrm{~mm}$

- Thickness of borosilicate glass tube $=1.5 \pm$ $0.1 \mathrm{~mm}$

- Composition of borosilicate glass $($ wt. $\%)=0.81$ $\mathrm{SiO}_{2}-0.13 \mathrm{~B}_{2} \mathrm{O}_{3}-0.05 \mathrm{Na}_{2} \mathrm{O}+\mathrm{K}_{2} \mathrm{O}-0.02 \mathrm{Al}_{2} \mathrm{O}_{3}$ *

For those alloys that are solid-liquid mixtures at $268^{\circ} \mathrm{C}$, the solid is expected to be $(\mathrm{Ni}, \mathrm{Cu})_{3} \mathrm{Sn}_{4}$ or $(\mathrm{Cu}, \mathrm{Ni})_{6} \mathrm{Sn}_{5}$ based on past research. ${ }^{17,19,20}$ Although the phase equilibria are not well established, it is expected that the fraction of any IMC present in these alloys at $268^{\circ} \mathrm{C}$ is very low (e.g., binary $\mathrm{Sn}-2 \mathrm{Cu}$ is calculated to contain only $\sim 1 \% \mathrm{Cu}_{6} \mathrm{Sn}_{5}$ and $99 \%$ liquid at $268^{\circ} \mathrm{C}^{30}$ ). Additionally, both IMC phases are denser than liquid $\mathrm{Sn}^{31-33}$ (Table II) and the $\sim 1 \%$ of IMC would be expected to settle/sediment to the bottom of the crucible during $1 \mathrm{~h}$ of isothermal holding at $268^{\circ} \mathrm{C}$. Similar IMC settling has been reported in the $\mathrm{Sn}-\mathrm{Ag}-\mathrm{Zn}$ system when IMC + liquid mixtures are held for extended periods. ${ }^{34}$ The fluidity apparatus was therefore designed so that any IMCs that formed and settled at $268^{\circ} \mathrm{C}$ would not be drawn into the glass tube, by locating the tube in the upper half of the crucible (Fig. 3b). After fluidity experiments, a fluidity tube from each bulk composition, $C_{0}$, was opened and the alloy was completely remelted into a chemical analysis sample. The composition was then measured by XRF spectroscopy in a Shimadzu XRF1700. This measurement provides the composition of the alloy drawn into the fluidity tube, and is therefore the liquid composition at $268^{\circ} \mathrm{C}, C_{\mathrm{L}}^{268}$, for the bulk composition, $C_{0}$.

The second series of experiments investigated the IMCs that form and settle at $268^{\circ} \mathrm{C}$. Ingots $(80 \mathrm{~g})$ from selected bulk compositions, $C_{0}$, were remelted

*Tube dimensions and material data were provided by Duran glass. 
in tapered stainless-steel cups coated with BN. The samples were held at $268 \pm 0.5^{\circ} \mathrm{C}$ for $16 \mathrm{~h}$ in an aircirculating furnace, and the alloys were then abruptly quenched in an ice-water slurry. A JEOL JSM-6460LA scanning electron microscope (SEM) was used to confirm whether IMCs had formed and settled and SEM energy-dispersive x-ray spectroscopy (EDX) was used to identify the IMC composition, $C_{\mathrm{IMC}}$, at $268^{\circ} \mathrm{C}$ for the bulk composition, $C_{0}$. The compositions of at least ten different IMC particles were measured for each sample where IMC settling occurred.

For microstructural analysis of both fluidity samples and $16 \mathrm{~h}$ isothermal holding samples, specimens were prepared by sectioning with a band saw, mounting in epoxy resin, grinding using 220 to $4000 \mathrm{SiC}$ papers, polishing with $6-\mu \mathrm{m}, 3-\mu \mathrm{m}$, and $1-\mu \mathrm{m}$ diamond suspension, and finished by polishing with $0.05-\mu \mathrm{m}$ colloidal silica.

\section{RESULTS AND DISCUSSION}

In presenting the results, alloys are named by their nominal compositions in wt.\%, but all compositions shown in the plots are the measured values $\left(C_{0}\right.$ and $C_{\mathrm{L}}^{268}$ by XRF spectroscopy, $C_{\mathrm{IMC}}$ by SEM$\mathrm{EDX}) . C_{0}$ and $C_{\mathrm{L}}^{268}$ are expressed in wt.\% since this is most relevant to solder alloys. The compositions of intermetallics, $C_{\mathrm{IMC}}$, are expressed in at.\% so that the stoichiometry can be easily deduced.

\section{IMC Settling and Phase Equilibria at $268^{\circ} \mathrm{C}$}

Figure $4 \mathrm{a}-\mathrm{c}$ shows the change in liquid composition from $400^{\circ} \mathrm{C}$ to $268^{\circ} \mathrm{C}$ for $75 \mathrm{Sn}-\mathrm{Cu}-\mathrm{Ni}$ alloys in the ranges of 0 wt.\% to $1.5 \mathrm{wt} . \% \mathrm{Cu}$ and 0 wt.\% to 0.3 wt.\% Ni. Examining the binary $\mathrm{Sn}-\mathrm{Cu}$ alloys in Fig. $4 \mathrm{a}$, there is no significant change in liquid composition from $400^{\circ} \mathrm{C}$ to $268^{\circ} \mathrm{C}$ for most bulk compositions, consistent with these alloys being fully liquid at $268^{\circ} \mathrm{C}$. However, at $C_{0}=1.5 \mathrm{wt} . \% \mathrm{Cu}$, the liquid composition is lower at $268^{\circ} \mathrm{C}$, as would be expected if an IMC formed and settled. $\mathrm{Sn}-1.5 \mathrm{Cu}$ is predicted to have a liquidus temperature of $264^{\circ} \mathrm{C}^{30}$ and is therefore close to the liquidus at $268^{\circ} \mathrm{C}$. The small discrepancy between the measured and predicted behavior is most likely due to impurities in these commercial-purity alloys. In the binary $\mathrm{Sn}-\mathrm{Ni}$ alloys in Fig. $4 \mathrm{~b}, C_{\mathrm{L}}^{268}=C_{0}$ for alloys containing 0 wt.\% to 0.17 wt.\% Ni, indicating that these compositions are liquid at $268^{\circ} \mathrm{C}$. Alloys containing higher $\mathrm{Ni}$ contents exhibited a significantly decreased liquid composition at $268^{\circ} \mathrm{C}$ and had $C_{\mathrm{L}}^{268} \approx 0.17 \mathrm{wt} . \% \mathrm{Ni}$ in all cases, indicating that the approximate liquidus composition of hypereutectic $\mathrm{Sn}-\mathrm{Ni}_{3} \mathrm{Sn}_{4}$ alloys at $268^{\circ} \mathrm{C}$ is about 0.17 wt.\% $\mathrm{Ni}$. Figure $4 \mathrm{c}$ shows a vector plot of the change in liquid composition for all alloys investigated. The start of a vector marks $C_{0}$, while the arrow head indicates $C_{\mathrm{L}}^{268}$. Where only arrow heads are visible, the change in composition is negligible. Approximately half of the alloys show a significant change in liquid
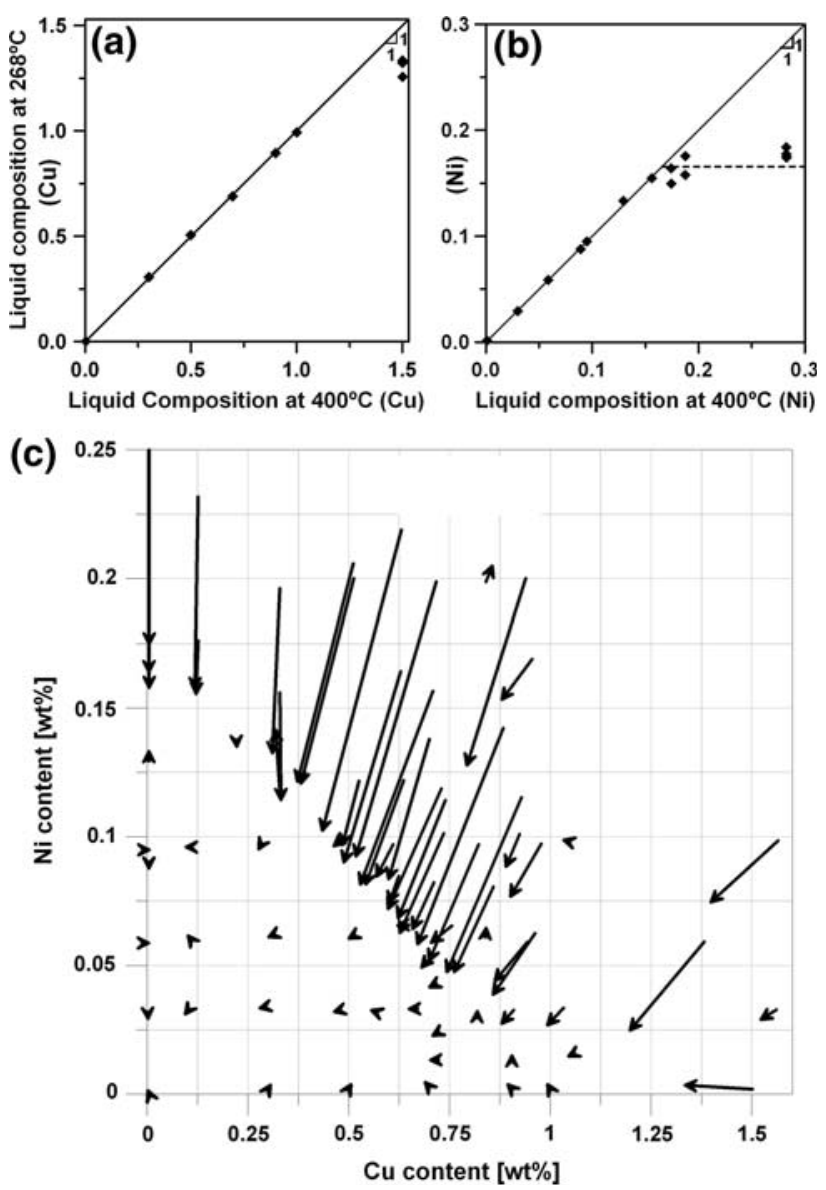

Fig. 4. The change in liquid composition from $400^{\circ} \mathrm{C}$ to $268^{\circ} \mathrm{C}$ in (a) binary $\mathrm{Sn}-\mathrm{Cu}$, (b) binary $\mathrm{Sn}-\mathrm{Ni}$, and (c) ternary $\mathrm{Sn}-\mathrm{Cu}-\mathrm{Ni}$. Compositions are in wt.\%. In (c) the start of each vector is the composition of the melt at $400^{\circ} \mathrm{C}$, while the arrow head indicates the composition in the fluidity tube at $268^{\circ} \mathrm{C}$.

composition from $400^{\circ} \mathrm{C}$ to $268^{\circ} \mathrm{C}$, indicating that they are partially solid at $268^{\circ} \mathrm{C}$. Although some vectors do not point to a continuous line, the large number of compositions investigated allows the liquidus contour at $268^{\circ} \mathrm{C}$ to be observed over much of its length.

The $16 \mathrm{~h}$ isothermal holding experiments confirmed that the changes in liquid composition measured in Fig. 4 are due to IMC formation and settling at $268^{\circ} \mathrm{C}$. Figure 5 shows the bottom of an isothermal holding cup where a sedimented layer of IMCs is clearly visible. Twenty compositions were selected for $16 \mathrm{~h}$ isothermal holding experiments, spanning all compositions where settling was implicated in Fig. 4c. In all 20 compositions, IMC settling was confirmed, similar to Fig. 5a. To quantify the compositions of IMCs, ten different IMC particles were measured by SEM-EDX for each value of $C_{0}$. For all compositions investigated, only one IMC phase was found for each bulk composition, either $(\mathrm{Cu}, \mathrm{Ni})_{6} \mathrm{Sn}_{5}$ or $(\mathrm{Ni}, \mathrm{Cu})_{3} \mathrm{Sn}_{4}$. Table III presents the mean measured $C_{\mathrm{IMC}}, C_{\mathrm{L}}^{268}$, and $C_{0}$ for the 20 alloys investigated. $(\mathrm{Cu}, \mathrm{Ni})_{6} \mathrm{Sn}_{5}$ was measured to have a $\mathrm{Ni}$ content throughout the range of 0 at. $\%$ to 23 at. $\% \mathrm{Ni}$ 

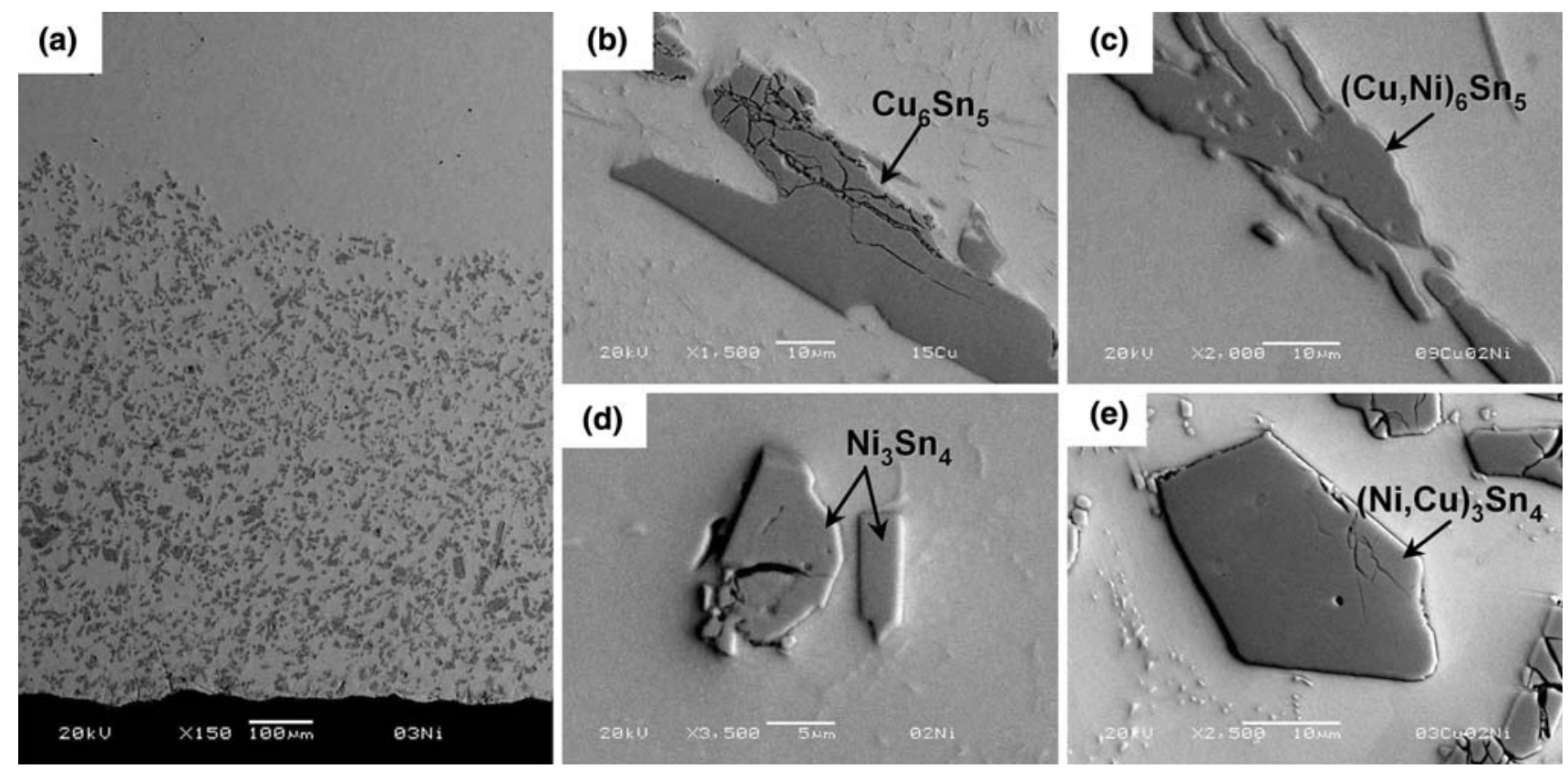

Fig. 5. SEM back-scattered electron (BSE) images of IMCs that settled during $16 \mathrm{~h}$ at $268^{\circ} \mathrm{C}$. (a) Layer of IMCs that settled at the bottom of a

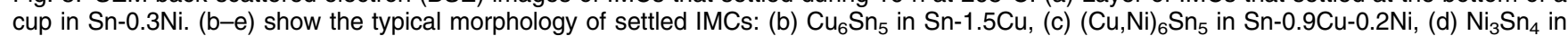
$\mathrm{Sn}-0.2 \mathrm{Ni}$, and (e) $(\mathrm{Ni}, \mathrm{Cu})_{3} \mathrm{Sn}_{4}$ in $\mathrm{Sn}-0.3 \mathrm{Cu}-0.2 \mathrm{Ni}$.

depending on $C_{0}$ (Table III) and no evidence was found for the presence of a $\left(\mathrm{Cu}, \mathrm{Ni}_{6}\right)_{6} \mathrm{Sn}_{5}$-type ternary compound at $268^{\circ} \mathrm{C}$. $(\mathrm{Ni}, \mathrm{Cu})_{3} \mathrm{Sn}_{4}$ was measured to have a $\mathrm{Cu}$ content throughout the range of 0 at.\% to 8 at. $\% \mathrm{Cu}$ depending on $C_{0}$ (Table III).

The mass fraction of IMC at $268^{\circ} \mathrm{C}$ was calculated from the measured values of $C_{0}, C_{\mathrm{L}}^{268}$, and $C_{\mathrm{IMC}}$ using the lever rule in Eq. 1. This equation is used because no concentration gradients were measured in the IMCs.

$$
f_{\mathrm{IMC}}=\frac{\left(C_{0}-C_{\mathrm{L}}^{268}\right)}{\left(C_{\mathrm{IMC}}-C_{\mathrm{L}}^{268}\right)}
$$

The mass fractions of IMCs are shown in Table III, where it can be observed that less than 1\% IMC settled in any alloy. Such a low phase fraction of IMC resulted in thin sedimented layers such as that shown in Fig. 5a.

Figure 5b-e shows typical settled IMC particles. Most IMC particles had a faceted morphology, but faceting was more pronounced in $\mathrm{Ni}_{3} \mathrm{Sn}_{4}$ than in $\mathrm{Cu}_{6} \mathrm{Sn}_{5} \cdot \mathrm{Ni}_{3} \mathrm{Sn}_{4}$ tended to form small, compact blocky particles (Fig. 5e), whereas $\mathrm{Cu}_{6} \mathrm{Sn}_{5}$ particles tended to be larger and were often branched as seen in Fig. 5c. There was considerable variation in IMC morphology between the multiple particles in each sample and, when comparing alloys, no systematic differences were detected between the morphology of $(\mathrm{Cu}, \mathrm{Ni})_{6} \mathrm{Sn}_{5}$ and $\mathrm{Cu}_{6} \mathrm{Sn}_{5}$ or the morphology of $(\mathrm{Ni}, \mathrm{Cu})_{3} \mathrm{Sn}_{4}$ and $\mathrm{Ni}_{3} \mathrm{Sn}_{4}$.

Figure $6 \mathrm{a}$ and $\mathrm{b}$ shows the isothermal section at $268^{\circ} \mathrm{C}$ based on the measured data in Table III. Figure $6 \mathrm{a}$ shows the entire Sn-rich half of the section, and Fig. $6 \mathrm{~b}$ focuses on the very Sn-rich corner relevant to the bulk compositions used. Figure $6 \mathrm{a}$ shows the full tie-lines, highlighting the large solubility of $\mathrm{Ni}$ in $(\mathrm{Cu}, \mathrm{Ni})_{6} \mathrm{Sn}_{5}$ and the smaller, but significant, solubility of $\mathrm{Cu}$ in $(\mathrm{Ni}, \mathrm{Cu})_{3} \mathrm{Sn}_{4}$. Since none of our bulk compositions contained the threephase mixture, $\mathrm{L}+(\mathrm{Cu}, \mathrm{Ni})_{6} \mathrm{Sn}_{5}+(\mathrm{Ni}, \mathrm{Cu})_{3} \mathrm{Sn}_{4}$, at $268^{\circ} \mathrm{C}$, we do not have data on the boundaries of the three-phase tie triangle. However, the boundaries must be more solute rich than the most solute-rich IMCs measured: $(\mathrm{Cu}, \mathrm{Ni})_{6} \mathrm{Sn}_{5}$ with 23 at. $\% \mathrm{Ni}$ and $(\mathrm{Ni}, \mathrm{Cu})_{3} \mathrm{Sn}_{4}$ with 8 at.\% $\mathrm{Cu}$ (Table III).

In plotting Fig. $6 \mathrm{~b}$, the liquidus contour is based on a best-fit smooth curve through the vector heads in Fig. 4c and the identity of the IMCs from Table III. The data points $C_{\mathrm{L}}^{268}$ and $C_{0}$ are plotted with a unique symbol for each alloy. The tie-lines are plotted through the data points $C_{0}$ and $C_{\text {IMC }}$ which pass very close to the data point $C_{\mathrm{L}}^{268}$ in most cases, confirming that the measurements closely approximate a tie-line. Figure $6 \mathrm{~b}$ suggests that no bulk composition was in the tie-triangle at $268^{\circ} \mathrm{C}$ because the apex of the tie-triangle is so narrow in this composition range. The tie-triangle has been estimated with cross-hatching in Fig. $6 \mathrm{~b}$.

Figure $7 \mathrm{a}$ and $\mathrm{b}$ compares the measured isothermal section with the literature. Figure $7 \mathrm{a}$ is the Sn-rich half of the section, and includes three experimental studies from the literature that used high-purity alloys, traditional phase equilibria determination techniques, and similar isothermal temperatures $\left(220^{\circ} \mathrm{C}\right.$ and $\left.240^{\circ} \mathrm{C}\right){ }^{17,19,20}$ The variation in liquidus contour with temperature does not influence the isothermal section significantly at the scale shown in Fig. 7a, and literature results can be 


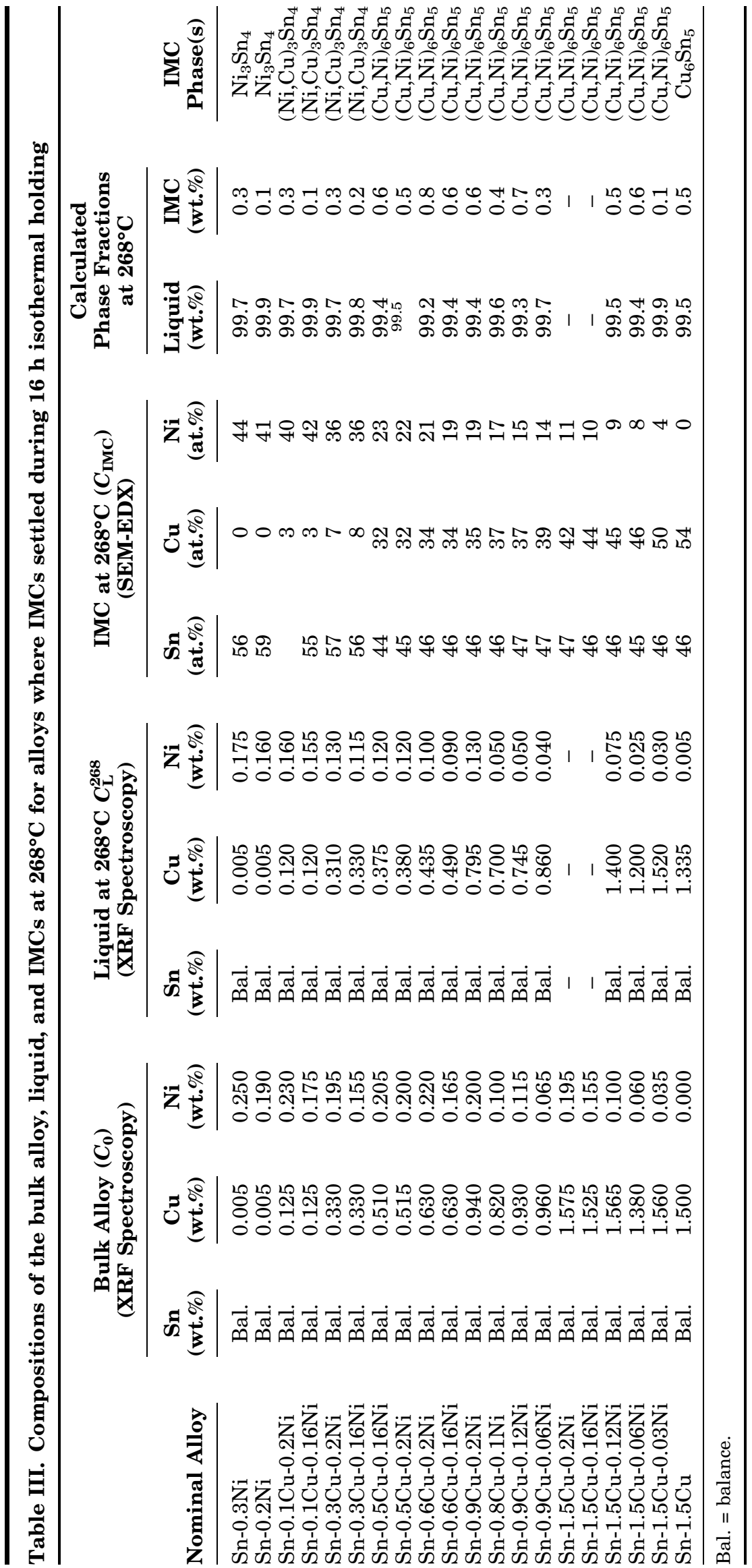



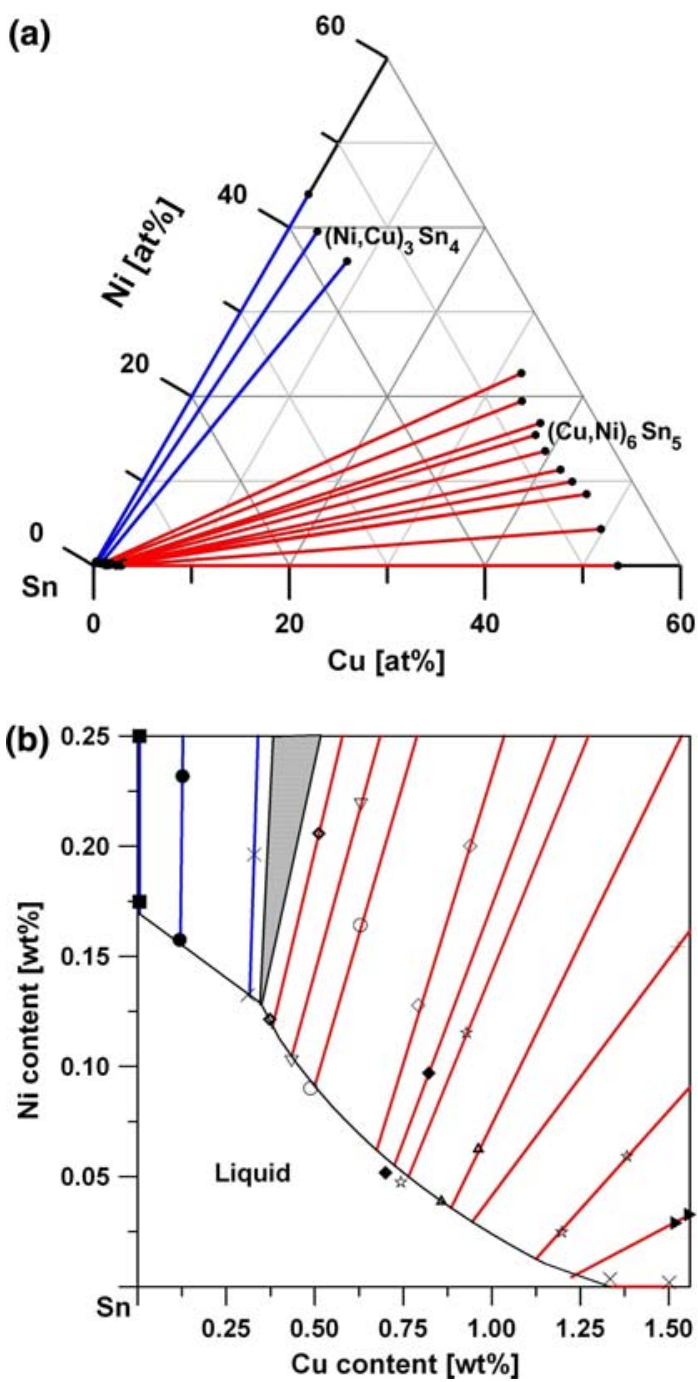

Fig. 6. Experimentally determined $\mathrm{Sn}-\mathrm{Cu}-\mathrm{Ni}$ isothermal section at $268^{\circ} \mathrm{C}$. Tie-lines are plotted as lines intersecting the points $C_{\mathrm{IMC}}$ and $C_{0}$. Red tie-lines are $\mathrm{L}+\left(\mathrm{Cu}, \mathrm{Ni}_{6} \mathrm{Sn}_{5}\right.$, blue tie-lines are $\mathrm{L}+(\mathrm{Ni}, \mathrm{Cu})_{3} \mathrm{Sn}_{4}$. (a) $\mathrm{Sn}$-rich half in at.\%. Data points show the measured values of $C_{\mathrm{IMC}}$ and $C_{0}$. (b) Very Sn-rich corner in wt.\%. The liquidus contour is based on the data in Fig. $2 \mathrm{c}$ and Table III. Data points show the measured values of $C_{\mathrm{L}}$ and $C_{0}$ where each alloy has a different symbol. The three-phase tie triangle is estimated by the cross-hatched region.

used to estimate the influence of temperature on the composition of the equilibrium IMCs in the range from $220^{\circ} \mathrm{C}$ to $268^{\circ} \mathrm{C}$ : Schmetterer et al.$^{20}$ published isothermal sections at $400^{\circ} \mathrm{C}$ and $220^{\circ} \mathrm{C}$. Their plots show that, in this temperature range, the changes in solubility limit of $(\mathrm{Ni}, \mathrm{Cu})_{3} \mathrm{Sn}_{4}$ and $(\mathrm{Cu}, \mathrm{Ni})_{6} \mathrm{Sn}_{5}$ are relatively small. $(\mathrm{Cu}, \mathrm{Ni})_{6} \mathrm{Sn}_{5}$ shows the largest variation of the two IMCs and the solubility limit varies from $\sim 29$ at. $\% \mathrm{Ni}$ at $400^{\circ} \mathrm{C}$ to $\sim 24$ at. $\% \mathrm{Ni}$ at $220^{\circ} \mathrm{C} .^{20}$ Assuming this relation to be linear, the change in $\mathrm{Ni}$ solubility from $220^{\circ} \mathrm{C}$ to $268^{\circ} \mathrm{C}$ is an increase of only $\sim 1$ at. $\% \mathrm{Ni}$, allowing us to compare the isothermal section in Fig. 6a with Refs. 17, 19, and 20 . The tie-triangles of Schmetterer et al. ${ }^{20}$ and $\mathrm{Li}$ et al. ${ }^{19}$ are consistent with our most solute-rich
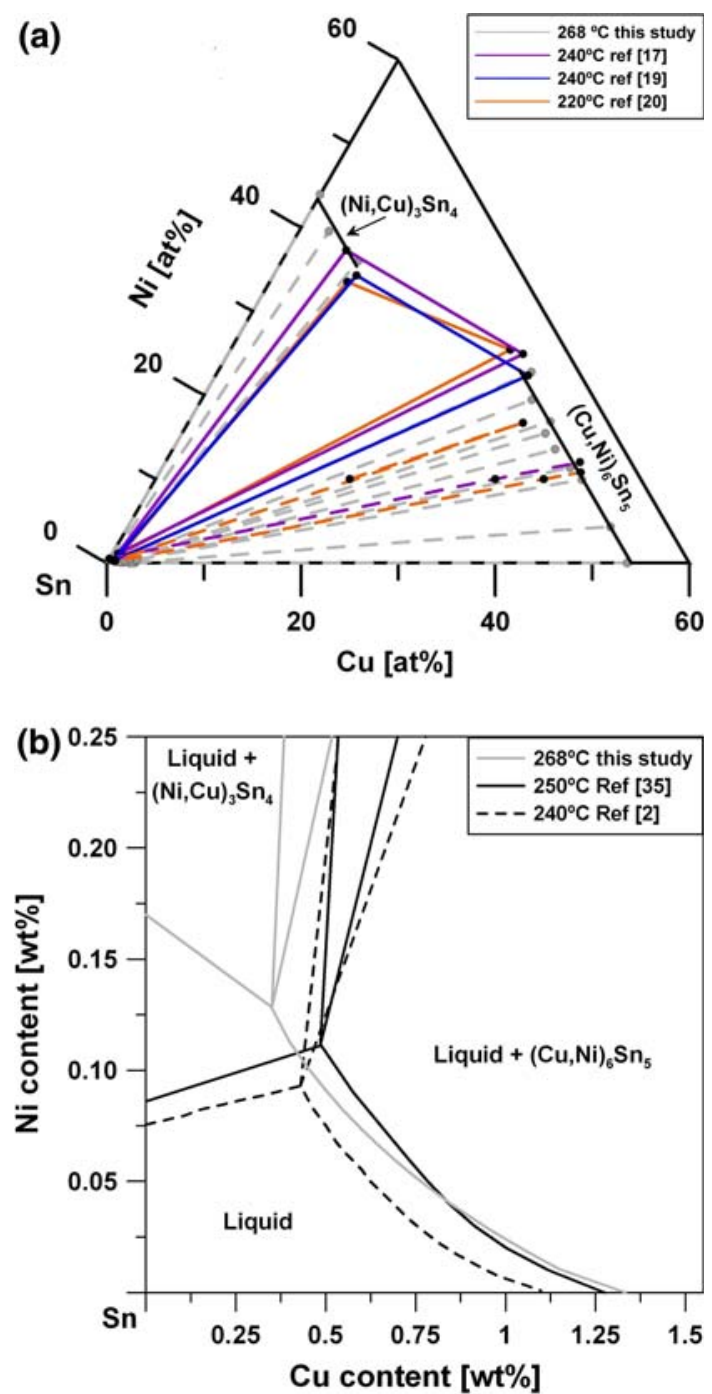

Fig. 7. Comparison of the isothermal section at $268^{\circ} \mathrm{C}$ with the literature. (a) Past experimental studies on the Sn-rich half at $220^{\circ} \mathrm{C}$ and $240^{\circ} \mathrm{C}$. Dashed lines are tie-lines, solid lines are phase boundaries. (b) Very Sn-rich corner showing calculated isothermal sections at $240^{\circ} \mathrm{C}$ and $250^{\circ} \mathrm{C}$ from Refs. 2 and 35 overlaid on the measured isothermal section.

tie-lines, although we have no data in the tietriangle itself. The tie-triangle of Lin et al. has a lower $\mathrm{Cu}$ composition in $(\mathrm{Ni}, \mathrm{Cu})_{3} \mathrm{Sn}_{4}$ than both our most $\mathrm{Cu}$-rich $(\mathrm{Ni}, \mathrm{Cu})_{3} \mathrm{Sn}_{4}$ tie-line and the tietriangles of Refs. 19 and 20. Figure 7a also contains tie-lines from the literature; only literature data for which $C_{\mathrm{L}}, C_{0}$, and $C_{\mathrm{IMC}}$ are near-linear have been used. Our measured $(\mathrm{Cu}, \mathrm{Ni})_{6} \mathrm{Sn}_{5}$ tie-lines are in good agreement with the data of Lin et al. ${ }^{17}$ and Schmetterer et al. ${ }^{20}$ (Fig. 7a). Thus, although a different technique has been used in this study, the results produce a similar isothermal section to previous experimental phase equilibria studies. ${ }^{17,19,20}$ Additionally, the results support studies that report a wide solubility range for $\left(\mathrm{Cu}, \mathrm{Ni}_{6} \mathrm{Sn}_{5}\right.$ with no ternary compound. 
No experimental studies on the liquidus contour near $268^{\circ} \mathrm{C}$ were found with which we can compare Fig. 6b. However, the calculated phase equilibria of $\mathrm{Yu}$ et al. ${ }^{35}$ and Vuorinen et al. ${ }^{2}$ are suitable for comparison. Figure $7 \mathrm{~b}$ shows the isothermal section at $268^{\circ} \mathrm{C}$ from Fig. $6 \mathrm{~b}$ with the calculated isothermal sections at $240^{\circ} \mathrm{C}^{2}$ and $250^{\circ} \mathrm{C}^{35}$ overlaid. There is a significant difference between our measured $(\mathrm{Ni}, \mathrm{Cu})_{3} \mathrm{Sn}_{4}$ liquidus contour and the calculated $(\mathrm{Ni}, \mathrm{Cu})_{3} \mathrm{Sn}_{4}$ contours from Refs. 2 and 35 . The liquidus projection in Fig. $1 \mathrm{~b}$ is from the same calculations as the two isothermal sections in Fig. $7 \mathrm{~b} .^{2}$ In Fig. $1 \mathrm{~b}$, the $\mathrm{Sn}-\mathrm{Cu}_{6} \mathrm{Sn}_{5}$ binary eutectic point is at $0.89 \mathrm{wt} . \% \mathrm{Cu}$, which is consistent with the literature. ${ }^{30}$ However, the $\mathrm{Sn}-\mathrm{Ni}_{3} \mathrm{Sn}_{4}$ binary eutectic point is plotted at $\sim 0.07 \mathrm{wt} . \% \mathrm{Ni}$ in Ref. 2 (and Fig. 1b), which is significantly less than the experimentally determined value of $0.16 \mathrm{wt} . \% \mathrm{Ni}$ which is used in the analysis of Nash and $\mathrm{Nash}^{36}$ and accepted in the work by Schmetterer et al. ${ }^{37} \mathrm{~A}$ $\mathrm{Sn}-\mathrm{Ni}_{3} \mathrm{Sn}_{4}$ binary eutectic composition of $0.16 \mathrm{wt} \%$ $\mathrm{Ni}$ requires a hypereutectic liquidus composition at $268^{\circ} \mathrm{C}$ of $C_{\mathrm{L}}^{268}>0.16$ wt. $\%$ Ni. The data in Fig. $4 \mathrm{~b}$ is consistent with this, giving an approximate liquidus composition of hypereutectic $\mathrm{Sn}-\mathrm{Ni}_{3} \mathrm{Sn}_{4}$ alloys at $268^{\circ} \mathrm{C}$ of 0.17 wt.\% $\mathrm{Ni}$. Using a value of $0.07 \mathrm{wt} . \%$ $\mathrm{Ni}$ rather than $0.16 \mathrm{wt} . \% \mathrm{Ni}$ for the binary eutectic will alter the entire isothermal section when viewed over the very Sn-rich compositions in Fig. $7 \mathrm{~b}$ and is most likely responsible for the differences between the measured and calculated isothermal sections in Fig. 7b. Given the altered $(\mathrm{Ni}, \mathrm{Cu})_{3} \mathrm{Sn}_{4}$ liquidus contour, the measured and calculated $(\mathrm{Cu}, \mathrm{Ni})_{6} \mathrm{Sn}_{5}$ liquidus contours are in reasonable agreement, particularly when we consider the narrow composition range in Fig. 7b.

Figures $4 \mathrm{c}$ and $6 \mathrm{~b}$ show that less than half of the compositions in the investigated composition space are fully liquid at $268^{\circ} \mathrm{C}$. Examining the literature, it seems that some soldering studies have used combinations of composition and temperature in the $\mathrm{Sn}-\mathrm{Cu}-\mathrm{Ni}$ system where IMC settling occurred. For example, a recent soldering study ${ }^{1,11}$ used Sn-0.7Cu-0.3Ni that was thought to be fully liquid in a bath at $255^{\circ} \mathrm{C}, 275^{\circ} \mathrm{C}$, and $295^{\circ} \mathrm{C}$. Figures $4 \mathrm{c}$ and $6 \mathrm{~b}$ suggest that this alloy was partially solid in the bath for at least some of the temperatures used. Although only a very small percentage of IMC forms during isothermal holding, the liquid composition can change significantly, which could significantly alter the alloy behavior and soldering results. Moreover, if some IMC forms, the particles may not be able to settle if there is forced convection (e.g., due to the standing wave in a solder bath) and IMC particles could therefore be incorporated into the soldering process.

\section{Fluidity Length}

Based on the isothermal section in Fig. 6b, maximum fluidity length, $L_{\mathrm{f}}$, data were only analyzed for compositions that are fully liquid at $268^{\circ} \mathrm{C}$. To assess whether the alloys with known phase equilibria behave in a similar manner to Fig. 2, Fig. 8 shows the maximum fluidity length, $L_{\mathrm{f}}$, data of the two binary alloys, Sn-Cu and Sn-Ni. The dashed vertical lines show the eutectic compositions from Refs. 30 and 36. Similar to past fluidity studies overviewed in the "Introduction" section and summarized in Fig. 2, there is a peak $L_{\mathrm{f}}$ value at the "pure" Sn composition and the fluidity decreases with dilute alloying in both $\mathrm{Sn}-\mathrm{Cu}$ and $\mathrm{Sn}-\mathrm{Ni}$. The decrease in $L_{\mathrm{f}}$ with alloy content is steeper in $\mathrm{Sn}-\mathrm{Cu}$ alloys than in Sn-Ni alloys. After the initial decrease in $L_{\mathrm{f}}$, both alloys behave differently from the classical behavior in Fig. 2 . In $\mathrm{Sn}-\mathrm{Cu}, L_{\mathrm{f}}$ reaches a minimum in the range of 0.25 wt. $\%$ to 0.7 wt. $\% \mathrm{Cu}$ and then increases with increasing $\mathrm{Cu}$ content through the eutectic composition and continues to increase to the highest composition measured,
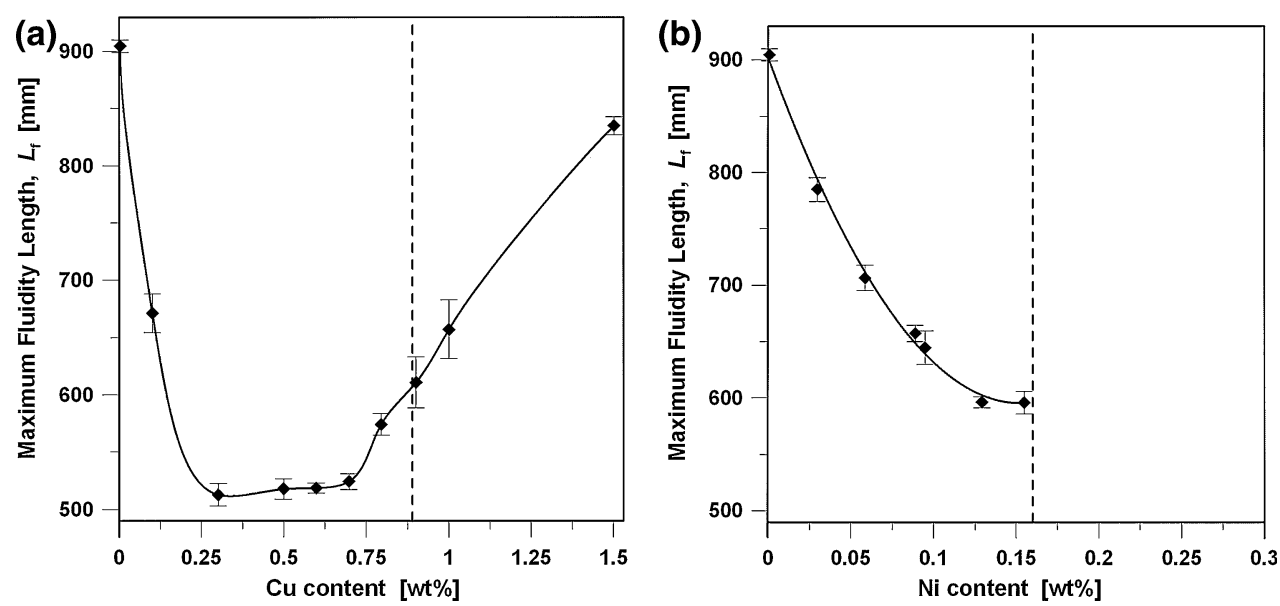

Fig. 8. Maximum fluidity length, $L_{f}$, at a constant initial melt temperature of $268^{\circ} \mathrm{C}$ for (a) $\mathrm{Sn}-x \mathrm{Cu}$, and (b) Sn- $x$ Ni binary alloys. Dashed vertical lines mark the eutectic compositions. Error bars are the standard deviations from five measurements. 
1.5 wt.\% Cu. Note, that the melt superheat $\left(268^{\circ} \mathrm{C}-T_{\text {liquidus }}\right)$ is decreasing from the eutectic composition to $1.5 \mathrm{wt} . \% \mathrm{Cu}$, yet $L_{\mathrm{f}}$ continues to rise. In Sn-Ni alloys, there is no increase in $L_{\mathrm{f}}$ after a minimum and the $L_{\mathrm{f}}$ remains approximately constant. Since the liquidus composition at $268^{\circ} \mathrm{C}$ for hypereutectic Sn-Ni alloys was measured to be $\sim 0.17$ wt.\% Ni (Fig. 4b), there was little scope to measure the fluidity at hypereutectic compositions in $\mathrm{Sn}-\mathrm{Ni}$ alloys at $268^{\circ} \mathrm{C}$. It should also be highlighted that the changes in $L_{\mathrm{f}}$ with composition in this study are large, with $\mathrm{Sn}-0.5 \mathrm{Cu}$ flowing approximately half the distance of commercial purity Sn under the same conditions.

Similar to the explanation in previous work, ${ }^{23}$ the lack of an $L_{\mathrm{f}}$ peak at the eutectic compositions in either alloy is most likely related to a combination of: first, the highly asymmetrical phase diagrams, which result in only small volume fractions of IMC forming at hypereutectic compositions in the composition ranges studied. For example, at $\mathrm{Sn}-1.5$ wt. $\% \mathrm{Cu}$, only 2 mass $\% \mathrm{Cu}_{6} \mathrm{Sn}_{5}$ is present when the eutectic reaction begins, ${ }^{30}$ which is unlikely to be sufficient to arrest flow. Second, both $\mathrm{Cu}_{6} \mathrm{Sn}_{5}$ and $\mathrm{Ni}_{3} \mathrm{Sn}_{4}$ are faceted phases (Fig. 5), so the eutectic coupled zone is expected to be skewed away from the Sn side and hypereutectic compositions are most likely required to create fully eutectic microstructures at a high cooling rate. ${ }^{29} \mathrm{~A}$ similar trend of $L_{\mathrm{f}}$ data increasing beyond the eutectic composition in non-faceted-faceted eutectics is reported for Al-Si alloys. ${ }^{38}$

Figure 9a-c shows all the fluidity length data for $\mathrm{Sn}-\mathrm{Cu}-\mathrm{Ni}$ alloys that are liquid at $268^{\circ} \mathrm{C}$. Figure 9a shows a plot of $L_{\mathrm{f}}$ versus $\mathrm{Cu}$ content for $\mathrm{Sn}-\mathrm{Cu}-\mathrm{Ni}$ alloys at five Ni levels. At all Ni levels, $L_{\mathrm{f}}$ initially decreases with increasing $\mathrm{Cu}$ content, reaches a minimum, and then increases with further $\mathrm{Cu}$ additions. With increasing $\mathrm{Ni}$ content the increase in $L_{\mathrm{f}}$ begins at a lower $\mathrm{Cu}$ content (Fig. 9a). Figure $9 \mathrm{~b}$ shows a plot of $L_{f}$ versus $\mathrm{Ni}$ content for $\mathrm{Sn}-\mathrm{Cu}-\mathrm{Ni}$ alloys at seven $\mathrm{Cu}$ levels. These data are best examined by combining Fig. $9 \mathrm{a}$ and $\mathrm{b}$ and creating $\mathrm{a}$ three-dimensional (3D) plot of $L_{\mathrm{f}}$ versus $\mathrm{Cu}$ and $\mathrm{Ni}$. Figure 9c shows a $3 \mathrm{D}$ interpolation of all $L_{\mathrm{f}}$ data for $\mathrm{Sn}-\mathrm{Cu}-\mathrm{Ni}$ alloys that are liquid at $268^{\circ} \mathrm{C}$. The interpolation is shown as a fluidity surface with a color scale defined on both Fig. 9a and b. Black diamonds mark the measured compositions, $C_{0}$, of the 36 alloys examined. The liquidus contour from Fig. 6 is shown, marking the boundary between fully liquid and partially solid compositions at $268^{\circ} \mathrm{C}$. When plotted in $3 \mathrm{D}$, the $L_{\mathrm{f}}$ measurements exhibited smooth changes in $\mathrm{Ni}-\mathrm{Cu}$ space and the differences between low and high fluidities are relatively large.

Beginning in the "pure" Sn corner, Fig. 9c shows that the maximum $L_{\mathrm{f}}$ in the system is at the "pure" Sn composition and that the $L_{\mathrm{f}}$ decreases rapidly with solute additions. The decrease in $L_{\mathrm{f}}$ is more gradual on the $\mathrm{Ni}$ side than the $\mathrm{Cu}$ side. Figure $9 \mathrm{c}$
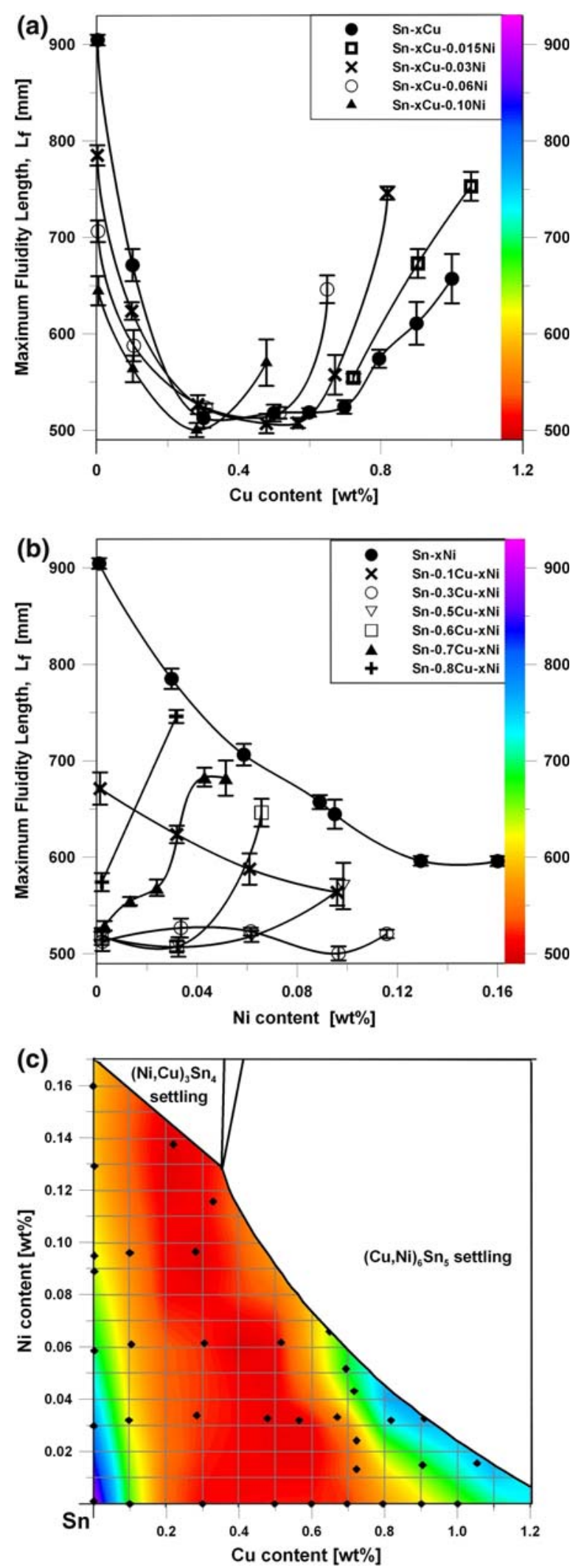

Fig. 9. $L_{f}$ data at $268^{\circ} \mathrm{C}$ for $\mathrm{Sn}-\mathrm{Cu}-\mathrm{Ni}$ alloys. (a) $L_{f}$ versus $\mathrm{Cu}$ content for five Ni levels. (b) $L_{f}$ versus $\mathrm{Ni}$ content for seven $\mathrm{Cu}$ levels. Error bars in (a) and (b) are standard deviations from five experiments. (c) Three-dimensional interpolation of all Sn-Cu-Ni $L_{f}$ data plotted as a fluidity surface with color scale bar shown on (a) and (b). 


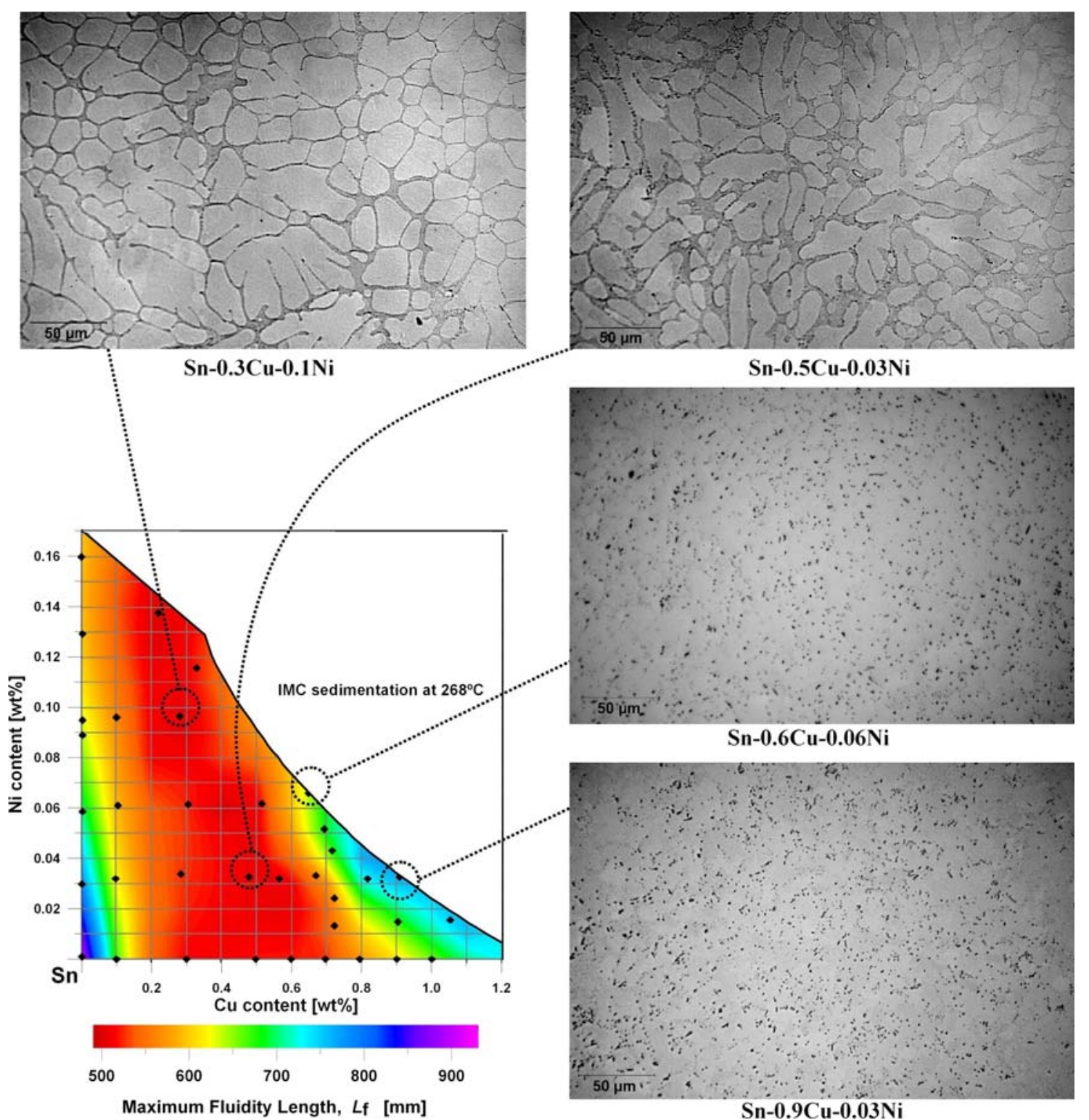

Fig. 10. Typical microstructures from Sn-Cu-Ni maximum fluidity length samples. Dashed lines show the composition of each sample on the fluidity map.

shows a "basin" of low fluidity, appearing orange and red, over a wide range of the compositions tested. The $L_{\mathrm{f}}$ then increases when the $\mathrm{Cu}$ content is larger than 0.6 wt.\% to 0.7 wt.\% $\mathrm{Cu}$. The highest fluidities (away from "pure" Sn) were measured close to the liquidus contour at $\mathrm{Cu}$ contents exceeding 0.7 wt.\% $\mathrm{Cu}$.

The isothermal section in Fig. 6 does not provide enough information to predict the solidification sequence of $\mathrm{Sn}-\mathrm{Cu}-\mathrm{Ni}$ alloys that are liquid at $268^{\circ} \mathrm{C}$. However, despite having many contradictions, the liquidus projections from the literature, shown in Fig. 1, can be compared with the fluidity map. Each of the liquidus projections in Fig. 1 contains at least one quasiperitectic reaction with a univariant valley leading to the binary $\mathrm{Sn}-\mathrm{Cu}_{6} \mathrm{Sn}_{5}$ eutectic point at $e_{2}=0.89 \mathrm{wt} . \% \mathrm{Cu}$. Comparing with the projection of Vuorinen et al. in Fig. 1b, the highest values of $L_{\mathrm{f}}$ are hypereutectic of the $\mathrm{Sn}+(\mathrm{Cu}, \mathrm{Ni})_{6} \mathrm{Sn}_{5}$ univariant valley. This is similar to the $L_{\mathrm{f}}$ increasing with increasing $\mathrm{Cu}$ content at hypereutectic compositions in binary $\mathrm{Sn}-\mathrm{Cu}$ (Fig. 8a). Comparing with the projection of Snugovsky et al. in Fig. 1a, the highest values of $L_{\mathrm{f}}$ are close to their lowest temperature-invariant point in Fig. 1a $\left(\mathrm{U}_{2}\right)$. In order to understand the form of the fluidity map in Fig. 9c further, we need to examine the fluidity tube microstructures.

Figure 10 compares the fluidity map with the microstructures formed in fluidity tubes. Four ternary compositions are shown, selected to cover the range of $L_{\mathrm{f}}$ values measured. The micrographs are 
representative of the trends observed in many compositions and are taken from $200 \mathrm{~mm}$ back from the flow tip where the scale of the microstructure is larger. The two compositions from the low-fluidity "basin" (Sn-0.3Cu-0.1Ni and $\mathrm{Sn}-0.5 \mathrm{Cu}-0.03 \mathrm{Ni}$ ) contain a significant fraction of primary $\beta$-Sn dendrites. In contrast, the two compositions shown which had high fluidity (Sn-0.7Cu-0.06Ni and $\mathrm{Sn}-0.9 \mathrm{Cu}-$ $0.03 \mathrm{Ni}$ ) do not contain any discernible $\beta$-Sn dendrites and contain a eutectic-like microstructure consisting of multiple IMC particles in a matrix of eutectic $\beta$-Sn. Due to their small size we cannot distinguish between primary IMCs and eutectic IMCs and these microstructures may either be neareutectic or mixtures of primary IMC and $\beta$-Sn + IMC eutectic. Since these microstructures formed at a relatively high cooling rate, it is not necessarily the case that the volume fractions of phases formed are those predicted by the equilibrium phase diagram (which is not known). In particular, the eutectic coupled zones are expected to be wider than just the univariant valleys or invariant points and also to be skewed away from the nonfaceted Sn side towards the faceted IMC sides. ${ }^{29}$ Since the cooling conditions in the fluidity test are not identical to those during soldering, it is useful to consider the $\mathrm{Sn}-\mathrm{Cu}-\mathrm{Ni}$ coupled zone further. Data is available in the literature for the binary $\mathrm{Sn}-\mathrm{Cu}_{6} \mathrm{Sn}_{5}$ eutectic coupled zone, determined by Machida et al. ${ }^{39}$ using unidirectional solidification. They report that this system is skewed toward the faceted $\mathrm{Cu}_{6} \mathrm{Sn}_{5}$ side, as expected. However, the influence of growth velocity on the $\mathrm{Sn}-\mathrm{Cu}_{6} \mathrm{Sn}_{5}$ coupled zone is not as marked as in $\mathrm{Al}-\mathrm{Si}^{29}$ or $\mathrm{Sn}-\mathrm{Ag}_{3} \mathrm{Sn},{ }^{39}$ and all growth rates in the range of $2 \mu \mathrm{m} \mathrm{s}^{-1}$ to $300 \mu \mathrm{m} \mathrm{s}^{-1}$ produced fully eutectic microstructures for compositions ranging from 0.9 wt. $\%$ to 1.2 wt. $\% \mathrm{Cu}^{39}$ Consistent with this, solidification studies on $\mathrm{Sn}-\mathrm{Cu}-\mathrm{Ni}$ alloys have found similar volume fractions of phases in samples cooled under a variety of conditions. For example, each of (i) unidirectional growth at $15 \mu \mathrm{m} \mathrm{s}^{-1}{ }^{40}$ (ii) multidirectional solidification at $0.5^{\circ} \mathrm{C} \mathrm{s}^{-1} 1^{14}$ and (iii) fluidity experiments ${ }^{23}$ produce $\mathrm{Sn}-0.7 \mathrm{Cu}$ containing Sn dendrite plus eutectic mixtures and Sn-0.7Cu-0.05Ni containing eutectic microstructures. Thus, although the cooling rate is expected to vary from one soldering process to another, for different joint dimensions/geometries, and between the fluidity test and some soldering processes, the fraction of phases and the fluidity behavior are not expected to differ widely from those in Figs. 9c and 10. Based on the coupled zone being skewed to the IMC sides, Sn-0.7Cu-0.06Ni and Sn-0.9Cu-0.03Ni in Fig. 10 could be hypereutectic despite forming fully eutectic microstructures. The microstructures in Fig. 10 are therefore more consistent with the liquidus projection of Vuorinen et al. ${ }^{2}$ in Fig. 1b, which predicts that both $\mathrm{Sn}-0.6 \mathrm{Cu}-0.06 \mathrm{Ni}$ and $\mathrm{Sn}-0.9 \mathrm{Cu}-0.03 \mathrm{Ni}$ are hypereutectic; and less consistent with the liquidus projection of Snugovsky et al. $^{16}$ in Fig. 1a, which predicts that $\mathrm{Sn}-0.6 \mathrm{Cu}-$
$0.06 \mathrm{Ni}$ is a hypoeutectic composition. Both projections correctly predict that $\mathrm{Sn}-0.3 \mathrm{Cu}-0.1 \mathrm{Ni}$ and $\mathrm{Sn}-0.5 \mathrm{Cu}-0.03 \mathrm{Ni}$ are hypoeutectic.

Past research has shown that the mechanism of flow stoppage in the fluidity test is dependent on the macroscopic solidification mode (Fig. 2). Figure 11 compares the fluidity map with the macroscopic solidification mode. Six compositions are shown, selected to cover the range of $L_{\mathrm{f}}$ values measured. For each alloy, the grain structure is shown for the flow tip and $200 \mathrm{~mm}$ back from the tip. At all compositions, the flow tip has an equiaxed grain structure, but $200 \mathrm{~mm}$ back there are significant differences in the microstructure between the alloys. Comparing Figs. 10 and 11 shows that the grains observed in Fig. 11 are either primary $\beta$-Sn grains or eutectic grains. At the "pure" Sn composition, which had the highest $L_{\mathrm{f}}$, a fully columnar macrostructure exists $200 \mathrm{~mm}$ back from the tip and there is a distinct shrinkage pipe at the flow tip, indicating that flow stoppage was by a pinching-off mechanism similar to that in Fig. 2c or d. For all other compositions examined, mixed columnarequiaxed solidification modes (e.g., Fig. 2f) were identified $200 \mathrm{~mm}$ from the flow tip. Figure 11 shows that, in the three compositions that had low values of $L_{\mathrm{f}}(\mathrm{Sn}-0.6 \mathrm{Cu}, \mathrm{Sn}-0.3 \mathrm{Cu}-0.1 \mathrm{Ni}$, and $\mathrm{Sn}-0.16 \mathrm{Ni}$ ), the columnar zone is significantly smaller than in the two compositions shown that had high values of $L_{\mathrm{f}}(\mathrm{Sn}-0.9 \mathrm{Cu}-0.03 \mathrm{Ni}$ and $\mathrm{Sn}-1.0 \mathrm{Cu}$ ). This trend cannot be meaningfully quantified here because (i) the samples are cylindrical and the polished plane may not be at the diameter, and (ii) there was significant variation in the extent of the columnar zone with position in each flow tube. However, the qualitative trend that alloys which solidified with a larger columnar zone have higher $L_{\mathrm{f}}$ values is clear. These observations are similar to the classical studies in the literature that originally linked solidification mode to fluidity length, as summarized in Fig. 2. Predicting the extent of the columnar zone during solidification of an alloy is complex and remains an active area of research today. ${ }^{41-43}$ In general, highly alloyed compositions where primary dendrites form typically have a large equiaxed zone, which can account for much of the low-fluidity "basin" in Fig. 9.

Although solidification in a cylindrical tube is not directly transferable to the case of solidification above a reactive joint during soldering, the fluidity map provides important information on the type of solder microstructure that forms during industrial soldering. Those compositions in the red low-fluidity "basin" tend to contain a significant fraction of primary $\beta$-Sn dendrites which will not only negatively influence flow behavior during wave soldering but also impact on the mechanical properties of the solder during service (irrespective of the soldering technique used). Those compositions in the green and blue regions (ignoring compositions near "pure" $\mathrm{Sn})$ tend to form near-eutectic microstructures 


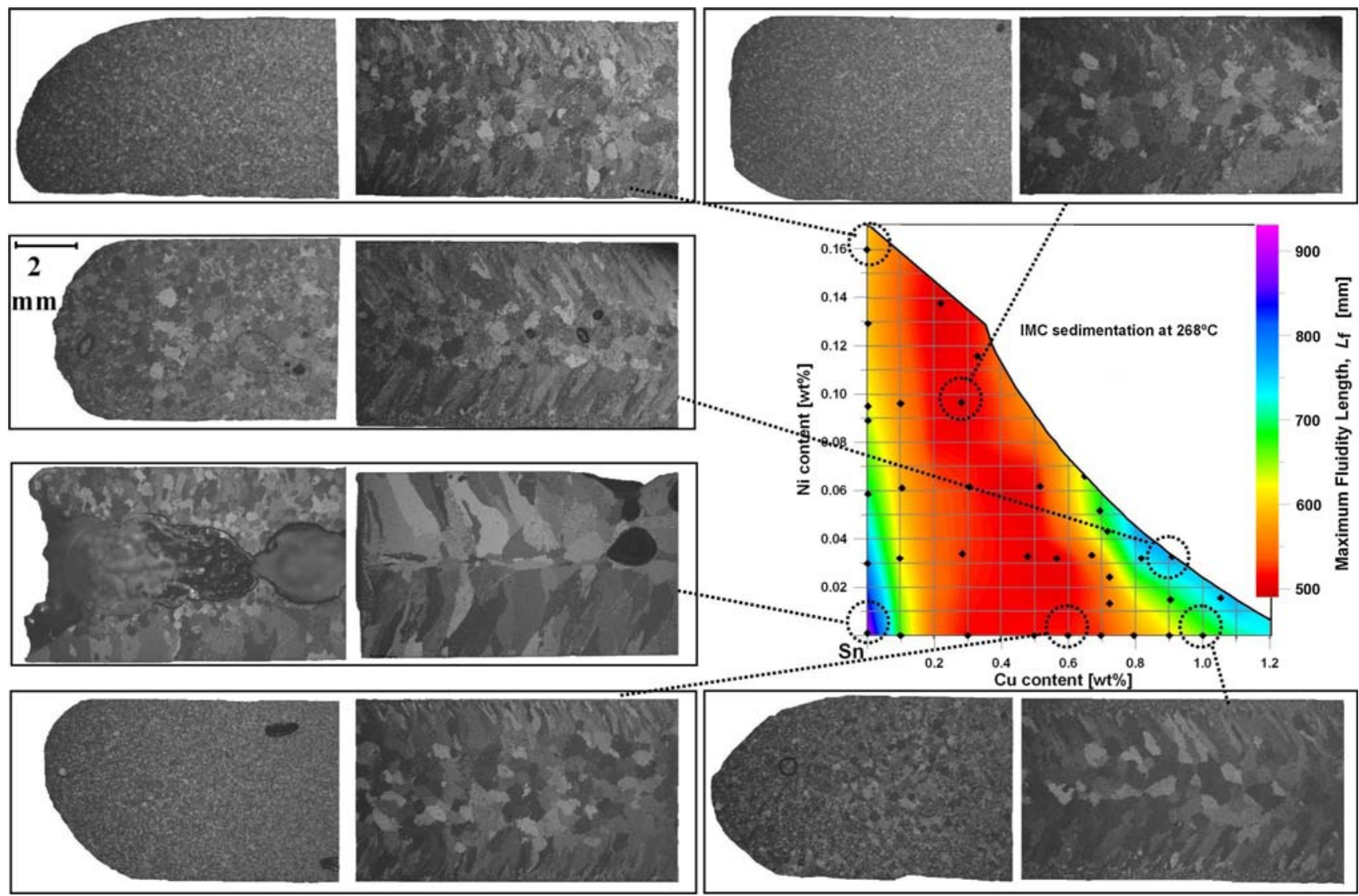

Fig. 11. Typical macrostructures from maximum fluidity length tests, focusing on compositions that exhibited extreme values of $L_{\mathrm{f}}$. Each box is one alloy with compositions indicated in the fluidity map with dashed lines. Within each box, the left-hand macrograph is the flow tip, and the other is $200 \mathrm{~mm}$ back from the tip.

which exhibit good flow properties during wave soldering and are expected to have more desirable mechanical properties in the final solder than compositions containing Sn dendrites.

\section{CONCLUSIONS}

A vacuum fluidity technique coupled with isothermal holding experiments have been used to study the phase equilibria and solidification behavior of very $\mathrm{Sn}$-rich $\mathrm{Sn}-\mathrm{Cu}-\mathrm{Ni}$ alloys containing 0 wt. $\%$ to 1.5 wt.\% $\mathrm{Cu}$ and 0 wt.\% to 0.3 wt.\% Ni at $268^{\circ} \mathrm{C}$. The isothermal section at $268^{\circ} \mathrm{C}$ was determined. No evidence for a ternary phase was found and the isothermal section was in good agreement with past experimental studies that report wide solubility ranges for $(\mathrm{Cu}, \mathrm{Ni})_{6} \mathrm{Sn}_{5}$ and $(\mathrm{Ni}, \mathrm{Cu})_{3} \mathrm{Sn}_{4}$. A significant proportion of the compositions examined are partially solid at $268^{\circ} \mathrm{C}$, containing mixtures of liquid and less than 1 mass\% of IMC. The IMC particles were shown to settle/sediment to the bottom of the crucible during extended holding times. The formation of even a very small fraction of IMC can significantly alter the liquid composition.

Compositions that are liquid at $268^{\circ} \mathrm{C}$ were used to generate a map of "maximum fluidity length" as a function of composition. Fluidity length is defined as the distance a cooling and solidifying alloy can flow in a constant cross-section before the developing microstructure arrests flow. Significant variations in fluidity length were measured among the Sn-Cu$\mathrm{Ni}$ alloys and these are correlated with the microstructure that develops during solidification. Similar to structural casting alloys, the highest values of fluidity length were measured for "pure" Sn and compositions which solidified with a near-eutectic microstructure. The fluidity map therefore provides a tool to select $\mathrm{Sn}-\mathrm{Cu}-\mathrm{Ni}$ solder compositions that exhibit good fluidity behavior during solidification and form near-eutectic microstructures.

\section{ACKNOWLEDGEMENTS}

The authors would like to thank Nihon Superior Co., Ltd., for funding and for their assistance in this research, producing the $\mathrm{Sn}-10 \mathrm{Cu}$ and $\mathrm{Sn}-10 \mathrm{Ni}$ master alloys, and conducting XRF spectroscopy on a large number of samples. We also thank Mr. Sreekanth Raghunath for conducting many of the fluidity experiments. C.M.G. thanks the Royal Academy of Engineering for a RAEng/EPSRC Research Fellowship. 


\section{REFERENCES}

1. M.J. Rizvi, C. Bailey, Y.C. Chan, M.N. Islam, and H. Lu, J. Alloys Compd. 438, 122 (2007).

2. V. Vuorinen, H. Yu, T. Laurila, and J.K. Kivilahti, J. Electron. Mater. 37, 792 (2008).

3. C.H. Wang and S.W. Chen, Metall. Mater. Trans. A 34A, 2281 (2003).

4. S.W. Chen, S.H. Wu, and S.W. Lee, J. Electron. Mater. 32, 1188 (2003).

5. V. Vuorinen, T. Laurila, T. Mattila, E. Heikinheimo, and J.K. Kivilahti, J. Electron. Mater. 36, 1355 (2007).

6. C.H. Wang and S.W. Chen, Acta Mater. 54, 247 (2006).

7. H. Nishikawa, J.Y. Piao, and T. Takemoto, J. Electron. Mater. 35, 1127 (2006).

8. J.W. Yoon, Y.H. Lee, D.G. Kim, H.B. Kang, S.J. Suh, C.W. Yang, C.B. Lee, J.M. Jung, C.S. Yoo, and S.B. Jung, J. Alloys Compd. 381, 151 (2004).

9. T. Laurila, V. Vuorinen, and J.K. Kivilahti, Mater. Sci. Eng. $R$ 49, 1 (2005).

10. K. Nogita and T. Nishimura, Scr. Mater. 59, 191 (2008).

11. M.J. Rizvi, C. Bailey, Y.C. Chan, and H. Lu, J. Alloys Compd. 438, 116 (2007).

12. J.X. Wang, S.B. Xue, Z.J. Han, S.L. Yu, Y. Chen, Y.P. Shi, and H. Wang, J. Alloys Compd. 467, 219 (2009).

13. T. Nishimura, S. Suenaga, and M. Ikeda, 4th Pacific Rim International Conference on Advanced Materials and Processing (PRICM4), ed. S. Hanada, Z. Zhong, S. Nam, and R. Wright (Honolulu, Hawaii, USA: The Japan Institute of Metals, 2001), p. 1087.

14. T. Ventura, C.M. Gourlay, K. Nogita, T. Nishimura, M. Rappaz, and A.K. Dahle, J. Electron. Mater. 37, 32 (2008).

15. C.M. Gourlay, K. Nogita, S.D. McDonald, T. Nishimura, K. Sweatman, and A.K. Dahle, Scr. Mater. 54, 1157 (2006).

16. L. Snugovsky, P. Snugovsky, D.D. Perovic, and J.W. Rutter, Mater. Sci. Technol. 22, 899 (2006).

17. C.H. Lin, S.P. Chen, and C.H. Wang, J. Electron. Mater. 31 907 (2002).

18. P. Oberndorff ( $\mathrm{PhD}$ thesis, Technical University Eindhoven, 2001).

19. C.Y. Li, G.J. Chiou, and J.G. Duh, J. Electron. Mater. 35, 343 (2006)

20. C. Schmetterer, H. Flandorfer, C. Luef, A. Kodentsov, and H. Ipser, J. Electron. Mater. 38, 10 (2008).
21. D.V. Ragone, C.M. Adams, and H.F. Taylor, AFS Trans. 64, 653 (1956).

22. M.C. Flemings, Solidification Processing (New Yrok: McGraw-Hill, 1974).

23. C.M. Gourlay, J. Read, K. Nogita, and A.K. Dahle, J. Electron. Mater. 37, 51 (2008).

24. K. Nogita, C.M. Gourlay, J. Read, T. Nishimura, S. Suenaga, and A.K. Dahle, Mater. Trans. (JIM) 49, 443 (2008).

25. J. Campbell, Castings (Oxford, UK: Butterworth Heinemann, 2003), pp. 74-98.

26. A. Portevin and P. Bastien, J. Inst. Met. 54, 45 (1934).

27. J.E. Niesse, M.C. Flemings, and H.F. Taylor, AFS Trans. 67, 685 (1959).

28. A.K. Dahle, P.A. Tondel, C.J. Paradies, and L. Arnberg, Metall. Mater. Trans. A 27, 2305 (1996).

29. W. Kurz and D.J. Fisher, Fundamentals of Solidification (Switzerland: Trans Tech Publications Ltd., 1998), pp. 108110.

30. Thermo-Calc (NIST Solder Solutions Database version 1.0) (1999)

31. P.J. Wray, Metall. Trans. B 7, 639 (1976).

32. A.K. Larsson, L. Stenberg, and S. Lidin, Acta Crystallogr. B 50,636 (1994).

33. T. Ishida, Metall. Mater. Trans. B 17, 281 (1986).

34. J.M. Song and K.L. Lin, J. Mater. Res. 18, 2060 (2003).

35. H. Yu, V. Vuorinen, and J.K. Kivilahti, J. Electron. Mater. 36,136 (2007).

36. P. Nash and A. Nash, Bull. Alloy Phase Diagrams 6, 350 (1985).

37. C. Schmetterer, H. Flandorfer, K.W. Richter, U. Saeed, M. Kauffman, P. Roussel, and H. Ipser, Intermetallics 15, 869 (2007).

38. G. Lang, Aluminium 48, 664 (1972).

39. J. Machida, H. Esaka, M. Tamura, and K. Shinozuka, J. Jpn. Inst. Met. 70, 73 (2006).

40. T. Ventura, C.M. Gourlay, K. Nogita, M. Rappaz, and A.K. Dahle, Proceedings of the International Conference and Exhibition on Materials and AustCeram 2009 (MA2009), Gold Coast, Australia (July 2009).

41. M.H. Burden and J.D. Hunt, Metall. Trans. 6, 240 (1975).

42. H.B. Dong and P.D. Lee, Acta Mater. 53, 659 (2005).

43. A. Badillo and C. Beckermann, Acta Mater. 54, 2015 (2006). 